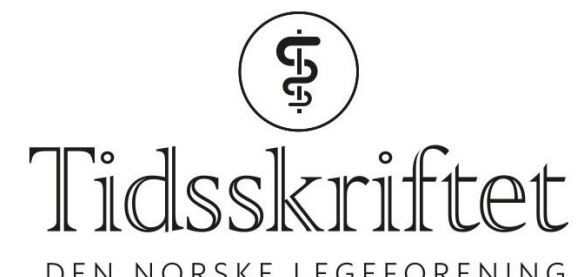

DEN NORSKE LEGEFORENING

\title{
Tolkning av EKG med kunstig intelligens
}

FRA ANDRE TIDSSKRIFTER

HAAKON B. BENESTAD

Universitetet i Oslo

Datamaskiner med dyplæring kan tolke EKG like godt som erfarne kardiologer.

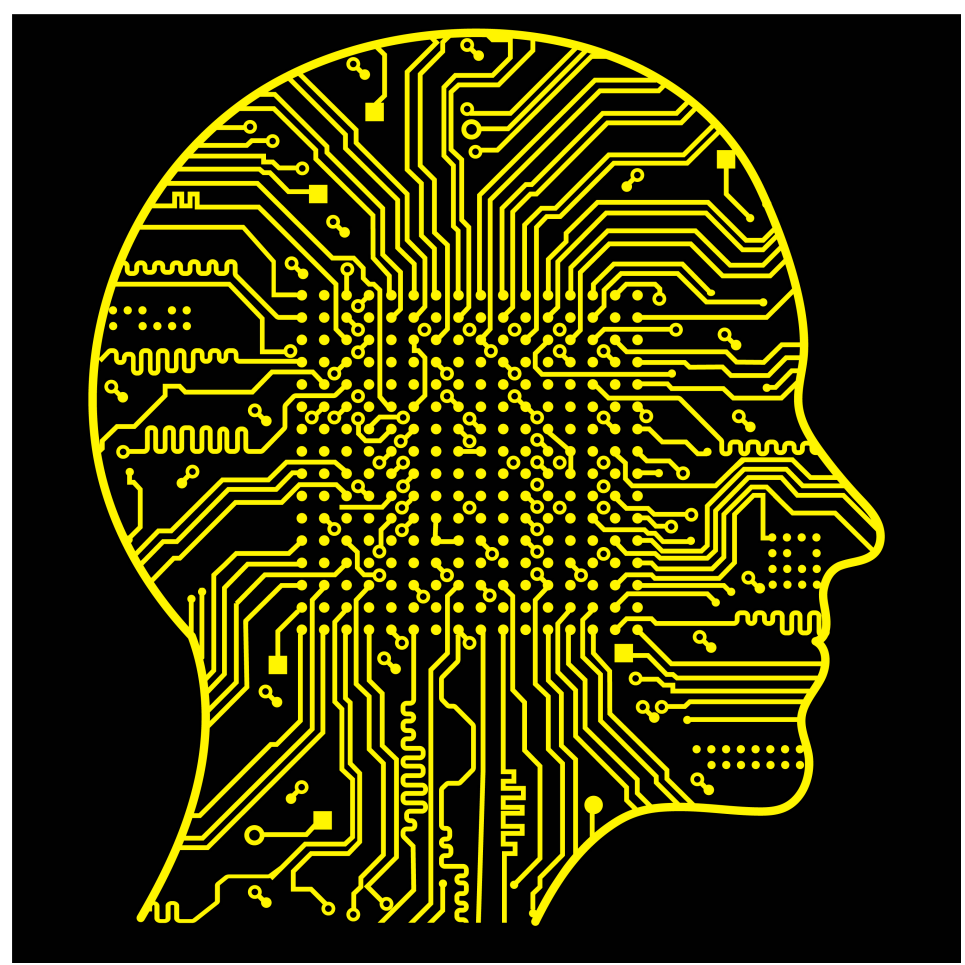

Illustrasjon: iStock

Kunstig (artifisiell) intelligens kommer til å revolusjonere medisinsk virksomhet. Selvlærende datamaskiner med kolossal kapasitet kan allerede i dag diagnostisere røntgenbilder og histopatologiske bilder. Maskinene «mates» med svære mengder digitaliserte normale og patologiske bilder, sammen med diagnosene. Datamaskinen lager så en algoritme, direkte fra data, uten programmering.

I en omfattende studie av EKG-tolkning lærte datamaskinen seg å diagnostisere 12 vanlig forekommende arytmier, f.eks. ventrikulære ekstrasystoler, på grunnlag av over 90 ooo ambulatoriske enkeltavlednings-EKG-målinger fra flere enn 50 ooo pasienter (1). Maskinen ble fôret med en «fasit», dvs. en konsensusdiagnose fra en gruppe kardiologer. Algoritmen 
som maskinlæringen resulterte i, ble så testet på et nytt materiale av EKG-målinger, der den diagnostiske sensitiviteten på over $90 \%$ var minst like god som kardiologenes. I en annen studie ble asymptomatisk hjertesvikt med ejeksjonsfraksjon $\leq 35 \%$ diagnostisert ved en tilsvarende prosess (2). Parvise EKG-målinger og ekkokardiogrammer fra rundt 36 ooo pasienter var brukt til konstruksjonen av algoritmen. Selvlærende maskiner kan ikke påvise EKG-funn som klinikeren normalt bruker, f.eks. QRS-bredde. På den annen side kan datamaskinen lære nye forskjeller mellom sykt og patologisk og anvende disse forskjellene i diagnostiseringen.

- Den mest avanserte formen for maskinlæring er såkalt dyp læring, der maskinen bruker mange lag av informasjon, velger bort informasjon den ikke trenger og dermed ligner litt på en menneskehjerne, sier Erik Fosse, som er professor og leder av Intervensjonssenteret ved Oslo universitetssykehus.

- Denne typen nettverk som maskinen bruker, kalles derfor gjerne for nevrale nettverk. Fosse påpeker at vi fortsatt vet lite om grensene for hva denne typen algoritmer kan utføre.

- Algoritmen velger selv hva den bruker av informasjon, så vi vet ikke hvordan maskinen kommer frem til sin konklusjon, det såkalte black box-problemet. Nevrale nettverk har vist seg å kunne løse viktige medisinske utfordringer allerede, så dette er bare begynnelsen, sier Fosse.

\section{LITTERATUR:}

1. Hannun AY, Rajpurkar P, Haghpanahi M et al. Cardiologist-level arrhythmia detection and classification in ambulatory electrocardiograms using a deep neural network. Nat Med 2019; 25: 65-9. [PubMed][CrossRef]

2. Attia ZI, Kapa S, Lopez-Jimenez F et al. Screening for cardiac contractile dysfunction using an artificial intelligence-enabled electrocardiogram. Nat Med 2019; 25: 70-4. [PubMed][CrossRef]

Publisert: 22. mars 2019. Tidsskr Nor Legeforen. DOI: 10.4045/tidsskr.19.0119

(C) Tidsskrift for Den norske legeforening 2020. Lastet ned fra tidsskriftet.no 